\title{
PATHOGENETIC MECHANISMS OF COMORBIDITY OF SYSTEMIC DISEASES AND PERIODONTAL PATHOLOGY
}

DOI: 10.36740/WLek202105140

\author{
Oksana M. Nemesh, Zoriana M. Honta, Oksana M. Slaba, Ihor V. Shylivskyi \\ DANYLO HALYTSKY LVIV NATIONAL MEDICAL UNIVERSITY, LVIV, UKRAINE
}

\begin{abstract}
The aim: $0 f$ the study is to analyze the literary data regarding evaluation of the pathogenetic mechanisms of the interaction of systemic diseases and periodontal tissue damage, conducted on the basis of scientific researches of Ukrainian and foreign scientists.

Materials and methods: Bibliosematic and analytical methods were used in the research. The materials of the exploration are international experience in the study of pathogenetic mechanisms of the interplay of pathology in the cardiovascular, respiratory systems, diseases of the gastrointestinal tract and chronic generalized damage of periodontal tissues. Conclusions: It is important to search for new modern methods of diagnosis and individual approach to primary and secondary prevention of changes in periodontal tissues on the background of general pathology. The only way to solve this problem is a detailed study of somatic and dental history, changes in all body systems, on the basis of which it is possible to create a reasonable set of individual preventive measures and improve the treatment of periodontal disorders.
\end{abstract}

KEY WORDS: periodontal diseases, systemic diseases, pathogenesis, cardiovascular pathology, diseases of the gastrointestinal tract, chronic obstructive pulmonary diseases

\section{INTRODUCTION}

Numerous scientific researches during many years have convincingly shown that systemic disorders in the human body, in one way or another are reflected in the condition of the organs and the oral cavity in the whole and periodontal tissues in particular. Herewith, the severity of periodontal damage is greater, the more severe and prolonged is the course of comorbid diseases, which, by negative influence on the system of protection of the human body, complicate the course of periodontal diseases. So, the mucous membrane of the oral cavity is an indicator of the presence of pathological processes in the body. The violation of a number of regulatory mechanisms, namely: microcirculation, neurohumoral regulation, immune and endocrine balance, psychosomatic factors, mineral metabolism, vitamin deficiency, the change of connective tissue metabolism, endotoxicosis, leads to weakening of organism's resistance and together with external factors (microbial colonization of the dental plaque) - to the development of periodontal diseases $[1,2,3,4]$.

\section{THE AIM}

The purpose of the study is to analyze the literary data regarding evaluation of the pathogenetic mechanisms of the interaction of systemic diseases and periodontal tissue damage, conducted on the basis of scientific researches of Ukrainian and foreign scientists.

\section{MATERIALS AND METHODS}

Bibliosematic and analytical methods were used in the research. The materials of the exploration are international experience in the study of pathogenetic mechanisms of the interplay of pathology in the cardiovascular, respiratory systems, diseases of the gastrointestinal tract and chronic generalized damage of periodontal tissues.

\section{REVIEW AND DISCUSSION}

During the recent years, scientists have evaluated the role of chronic inflammatory and dystrophic-inflammatory affection of periodontal tissues as a risk factor for the development of systemic diseases, including vascular atherosclerosis and its clinical manifestations (coronary heart disease, myocardial infarction) $[1,3,5]$. The inflammatory process in periodontal tissues is initiated by bacteria that enter the bloodstream and results in "asymptomatic bacteremia". In particular, this was demonstrated in the research in which periodontal bacteria were found in the smooth muscles of the coronary arteries as a result of transient bacteremia [6, 7]. Patients with generalized periodontitis, especially those colonized by gram-negative organisms such as $P$. gingivalis, Tannerella forsythensis, and Prevotella intermedia, have significantly higher levels of serum inflammatory markers, in particular C-reactive protein, Sh-6, and fibrinogen than in the persons without periodontitis. Effective treatment of inflammatory-dystrophic processes in periodontal tis- 
sues doesn't only reduce clinical symptoms, but also leads to a decrease in serum IL-6 and C-reactive protein levels [8]. This indicates that periodontal diseases have systemic effects that extend beyond the oral cavity.

Prevention and treatment without taking in to account the common factors of the etiopathogenesis of periodontal diseases and systemic somatic pathology is ineffective, has unstable long-term results, whereas the impact on individual pathogenesis links does not provide effective treatment and stabilization of pathological conditions with their comorbidity. The need for further research of the main pathogenetic mechanisms in development of inflammatory-dystrophic processes in periodontal tissues and the search of pathogenetically directed methods in treatment of this pathology remains an urgent problem of dentistry $[8,9]$.

The pathogenetic link between generalized periodontitis (GP) and diseases of the cardiovascular system is well established. Reducing stroke and minute volumes of the heart leads to a decrease in perfusion pressure in the vessels of the musculoskeletal system of the oral cavity and disturbance of microcirculation in the tissues of the gums, which is one of the factors that leads to the development of dystrophic changes $[10,11]$. Microvessels in periodontal tissue perform trophic and oxygen-generating function; make it a hydraulic apparatus, taking an active part in the biomechanics of the dento-mandibular segment, and circulation in periodontal tissues is 3-5 times more intensive than in other organs $[12,13]$. With the development of the inflammatory process in the tissues of the gums arises spastic state of arterioles, decreases the number of functioning capillaries, develops intravascular blood aggregation and impairs blood circulation. Changes of microcirculation appear at the violates the stages of development of dystrophic-inflammatory processes in periodontal tissues and cause the progression of the pathological process [13, 14]. The damage to the vascular wall during inflammation of periodontal tissues causes activation of intravascular adhesion and platelet aggregation, leading to local blood clotting with the possible development of disseminated intravascular coagulation syndrome. The changes in the system of hemostasis deepen the severity of inflammatory processes of the periodontium [10].

Parodontopathogenic bacteria are considered today as possible causes of sudden appearance of atherosclerosis and cardiovascular disease. One of such possibility is the translocation of oral bacteria into the atherosclerotic plaque [13]. The urgency of this issue has grown in connection with the appearance of a "unified theory of atherogenesis», which is considers of atherosclerosis, a leading factor in the development of cardiovascular disease, as an immune inflammatory process. In the updated recommendations of the European Society of Cardiology (ESC) and European Atherosclerosis Society (EAS) for the prevention of cardiovascular disease in the clinical practice, a separate section is devoted to the possible impact of chronic inflammatory diseases on the level of cardiovascular risk and the need for their detection and timely correction. In this section discusses separately the problem of having a patient with cardiovascular disease of dystrophic inflammatory periodontal disease and their possible relationship is discussed.

Chronic inflammatory and dystrophic-inflammatory diseases are considered as a risk factor for the development of a systemic inflammatory response that is the basis of atherosclerosis of the vessels $[10,15,16]$. The Consensus on Periodontitis and Atherosclerotic Cardiovascular Diseases, published in the American Journal of Cardiology and the Journal of Periodontology, recommends to inform patients with moderate and severe periodontitis about the possible increased risk of cardiovascular disease and the need for a cardiac examination [17].

Current research data confirm the presence of periodontopathogenic microorganisms in the atherosclerotic plaque of vessels. Q. Wang and co-authors found P. gingivalis in $42 \%$ of atheromatous formations [14]. W. Serra e Silva Filho and co-authors, examining the microbial landscape of the gums and atherosclerotic plaques, identified 17 identical phylotypes, which the authors consider as bacterial translocation between the microflora of the periodontal pockets and the coronary arteries [18]. These data confirm the works of E. Kozarov, as they made it possible to isolate viable Porphyromonas gingivalis in atherosclerotic plaque [19]. So, DNA of periodontal bacteria was detected in 10 out of 17 samples from the coronary arteries: Porphyromonas gingivalis was present in 52.9\%, Aggregatibacter actinomycetemcomitans - in $35.5 \%$, Prevotella intermedia - in $23.5 \%$, Tannerella forsythia - in $11.7 \%$ [20]. Microorganisms such as Chlamydia pneumoniae and Cytomegalovirus play an important role in the occurrence of atherosclerosis, which is confirmed by the presence of Chlamydia pneumoniae antibodies in patients with cardiovascular disease. Chronic oral infection with Chlamydia pneumoniae and Cytomegalovirus and other bacteria is also a risk factor for the development of hypertension and myocardial infarction $[15,21]$.

Possible pathogenetic changes that lead to an increase in the risk of atherosclerosis in patients with periodontal disease, J. Bartova and co-authors consider changes in the activity of proinflammatory and anti-inflammatory cytokines [22]. The recent researches have led to the formation of a «cytokine concept» of the development of chronic inflammation in periodontium.

According to this concept, activation of periodontopathogenic microflora of monocytes and macrophages increases the production of these cells by proinflammatory cytokines, causing an imbalance between their proinflammatory and anti-inflammatory pools, which is one of the main causes of periodontal tissue damage, which can lead to the formation of periodontal cysts $[23,24]$. The likelihood of development of cardiovascular disease is increased by inflammatory factors produced by chronic infectious process - C-reactive protein (CRP), increased leukocyte quantity and fibrinogen level in the blood, TNF-a, proinflammatory cytokines, which may be an independent risk factor for atherosclerosis [25].

O.V. Kopchak $[26,27]$ revealed in patients with GP changes in the bacterial spectrum of the biotope of the 
periodontal pockets biotope toward recognized periodontal pathogens: Treponema denticola (62,5\%), RogrIugoshopa gingivalis (70,83\%), Tannerella foreythensis (87,5\%), Povotella intetmedia (54.17\%), asymptomas actinomycetemcomitans (25\%) and the presence of wand microflora in each smear $(72 \%$ of patients - «many in sight») cause the production of heat shock proteins with a high level of identity (molecular mimicry) amino acid composition of proteins to human heat shock proteins, which is conformed with immunoblot analysis, which said that affinity-purified anti-Bair60 antibodies revealed from the blood of patients with hypertension were able to recognize Hsp60, are accumulated in periodontal tissues with GP. These data indicate the autoimmune nature of the disease and the presence of interdependent links in the pathogenesis of GP and cardiovascular pathology, based on the synthesis of antibodies against heat shock proteins that affect all stressed cells of the body, forming the chronicity of pathological processes $[27,28]$.

As the oral cavity is the part of the digestive tract, the unity of innervation and humoral regulation create the preconditions for the mutual influence of pathological processes in periodontal tissues and diseases of the gastrointestinal tract.

In violation of the digestive system, according to various literary data, periodontal damage was detected in $92 \%$ $-100 \%$ of the examined. The pathology of different sections of the digestive tract determines the clinical picture of periodontal tissue damage. The degree of severity of inflammatory-destructive processes in periodontal tissues correlates with the activity of inflammation in the gastrointestinal tract $[28,29]$.

Chronic inflammatory processes in the oral cavity and gastroduodenal zone are demonstated not only by inflammation of the mucous membranes caused by pathogenic microorganisms, but also by a complex combination of imbalance of barrier mechanisms, the mechanism of regulation of gastric secretion, oxidizingly recoverable reactions and cellular renewal. Violation of a number of regulatory mechanisms, namely: immune and endocrine balance, microcirculation, neurohumoral regulation, psychosomatic relationships, mineral metabolism, vitamin deficiency, alteration of connective tissue metabolism, endotoxicosis, according to scientists, leads to the reduction of organism resistance, and in combination with external factors (microbial colonization of the dental plaque) - to the development of periodontal diseases [30,31]. Rapid generalization of the inflammatory-destructive process in periodontal tissues is accompanied by disorders in the immune status of patients with gastritis, peptic ulcer and duodenal ulcer [28].

Helicobacter pylori is one of the main etiological factors in the development of inflammatory diseases of the gastrointestinal tract and periodontal, found in various parts of the oral cavity: in the mouth and in the gum fluid, on the mucous membrane of the tongue and cheeks, in the periodontal pockets.

It's proven that increasing the Helicobacter pylori infection rate leads to increasing the intensity of the dys- trophic-inflammatory process in periodontal tissues, it is revealed a high degree of bacterial insemination with anaerobic microflora, and this infection greatly aggravates the infection GP in such a category of patients [32, 33]. E.M. Ryabokon and co-authors [34] came to the conclusion that it is the alternative processes that occur in the periodontium in the GP on the background of peptic ulcer disease, create the conditions for the insemination of periodontal pockets of Helicobacter pylori, resulting in the latter are converted to the permanent source of infection of the lower sections of the gastrointestinal tract. Scientific research has proven the ineffectiveness of eradicating therapy aimed for destruction of Helicobacter pylori in the stomach without destroying the pathogen that persists in the oral cavity to. Its complete eradication and stabilization of the periodontal status results in simultaneous therapy of peptic ulcer and GP using local scheme of medication treatment for GP and anti-Helicobacter pylori drugs [32]. According to research N.V. Manaschuk [31], in patients with chronic colitis, the generalized inflammatory-dystrophic process in periodontal tissues is $21.9 \%$. The leading factor in the formation of the syntropy of inflammatory bowel disease and inflammatory periodontal disease, according to Z.V. Esayan [35], is a systemic disorder of the neurohumoral response that determines the activity of aggression factors and exhausts the body's compensatory capacities.

The tendency to generalized course of peri-inflammatory-dystrophic processes in periodontal tissues on the background of gastroesophageal reflux disease and chronic pancreatitis, researchers attribute to the violation of the dynamic equilibrium between the factors of aggression and protection, primarily due to disorders of neurohumoral gastrointestinal regulation [30].

In determining the pathogenetic features of periodontal diseases in patients with chronic pancreatitis, it was found that the violation of lipid metabolism in chronic pancreatitis leads to the violation of the sensitivity of the vessels of the microcirculatory bed to mediators and hormones, resulting in the development of periodontal dystrophy and reduce the resistence to the microflora of the oral cavity. The decrease in the total coagulation capacity of venous blood, the violation of formation of active prothrombinase, antiaggregation, anticoagulation and fibrinolytic activity of the vascular wall correlate with the frequency of detection of periodontal tissue diseases. In disorders of lipid metabolism, in the diseases of the pancreas, the sensitivity of the microcirculatory bed to mediators and hormones changes, resulting in to the development of periodontal tissues dystrophy and their resistance to the harmful effects of the oral microflora reduces. The development of pathological changes in periodontal tissues is associated with a sharp activation of microbial agents against the background of decline specific and nonspecific mechanisms of general and local defense $[28,30]$.

Clinical researches have established a close relationship between the chronic diseases of the hepatobiliary system and generalized inflammatory-dystrophic violation of periodontal tissues. Disorders of the antimicrobial function of 
the liver cause the excessive bacterial growth, resulting in dysbiotic changes in the oral cavity. Getting into the general circulation of some bacteria and toxins in case of violation of liver antimicrobial function can cause the development of local or systemic inflammation [36].

Viral hepatitis, in particular chronic hepatitis C, is capable to affect homeostasis disorders in oral cavity, causing the development of hyposalivation, which is clinically appeared by xerostomia, leading to the development and progression of periodontal diseases. Clinical manifestations GP have a clear dependence on the phase of activity of chronic viral hepatitis $\mathrm{B}$, the duration of the disease. Particularly close association of GP with viral hepatitis B, according to scientists, may be dependent both on the degree of overall activity of hepatitis and the emphasis of immunopathological disorders induced by hepatitis $B$ virus $[37,38]$.

The respiratory and digestive systems are anatomically and functionally connected through the oral cavity, and their diseases have common factors of development, such as smoking and microbial factors. In the structure of dental diseases in patients with chronic obstructive pulmonary diseases, the leading place is occupied by the pathology of the periodontium, which is clinically manifested by symptoms of GP I-II degrees of development and its complications - partial or complete secondary adentia, and in the conservation of teeth - defects of the dental rows, inclusion disorders functions, aesthetics [39].

G.S. Kharchenko-Sevryukova [40] indicates that in $27 \%$ of patients had been determined complete secondary adenitis, which occurred as a complication of GP; $46 \%$ of surveyed were diagnosed with grade I GP, $27 \%$ - with stage II development. The author emphasizes that the features of the course of generalized periodontal diseases against the background of chronic obstructive pulmonary diseases are the predominance of non-inflammatory but dystrophic-destructive processes of periodontal tissues with significant loss of attaching the gums, deep periodontal pockets and a high degree of microbial insemination.

According to scientists, the main factors that lead to the violation of mineral metabolism in bone tissue in patients with chronic obstructive pulmonary disease and affect the occurrence and course of GP, is hypoxia, which occurs during the progression of bronchial obstruction and causes chronic, inflammatory process increase of the level of proinflammatory cytokines, the development of chronic respiratory acidosis, decrease of physical activity and exercise tolerance [41].

In view of the significant importance of hypoxia in the mechanisms of the direct development of periodontal diseases. The specific attention is deserved by the data on the presence in patients with chronic obstructive pulmonary diseases of anemic hypoxia, due to inactivation of hemoglobin, due to endogenous intoxication [42].

\section{CONCLUSIONS}

Thus, dystrophic-inflammatory periodontal diseases have a complex multilevel nature of pathological changes with the gradual involvement of periodontal tissues structures, which leads to denoted clinical manifestations with violated periodontal function. The changes in periodontium are chronic with low anti-infective protection of the oral cavity. At the same time, immune reactions do not provide confrontation of the infected periodontium and become a pathogenetic basis of the chronic process. Among the risk factors are crucial disorders of oral microbiocynosis and imbalance of immune systems (production of antibodies to heat shock proteins and stimulation of the release of proinflammatory cytokines), lack of antioxidant protection, disorders of microcirculation and transcapillary exchange in dental tissues.

Inflammatory-dystrophic changes in periodontal tissues contribute to the increase of the level of chronic inflammatory agents due to the systematic spread of inflammatory mediators that are released during local tissue destruction, immune-inflammatory reactions to periodontal pathogens, as well as to the systemic spread of pathogenic microorganisms that can contribute to the development of pathogens. At the same time, the literature on immune reactivity in periodontal diseases is quite controversial, which may be explained by the fact that immune reactivity in patients with periodontitis is very variable: it depends on the severity, phase of the disease, type of inflammatory reaction, age, presence of comorbidities.

\section{REFERENCES}

1. Gurenlian J.R. Inflammation: the relationship between oral health and systemic disease. Dent Assist. 2009; 78(2):8-10,12-4,38-40. doi: 10.1016/j.pharmthera.2013.04.006.

2. Cullinan M.P., Ford P.J, Seymour G.J. Periodontal disease and systemic health: current status. Aust Dent J. 2009;1:62. doi: 10.1111/j.18347819.2009.01144.x.

3. Nemesh 0.M., Honta Z.M., Shilivskiy I.V., Skalat A.P. Vzaimosvyaz' zabolevaniy parodonta s somaticheskoy patologiyey [The relationship of periodontal disease with somatic pathology]. Stomatolohycheskyi zhurnal. 2011;1:18-21. (in Russian).

4. Shylivskyi I.V., Nemesh 0.M., Honta Z.M. Suchasni pohliady na etiolohiiu ta patohenez zapalnykh zakhvoriuvan parodonta, yikh vzaiemozviazok iz patolohiieiu sechovydilnoi systemy (ohliad literatury ta vlasni doslidzhennia). Bukovynskyi medychnyi visnyk. 2016;1:224-227. (in Ukrainian).

5. Nesse W., Spijkervet F.K., Abbas F., Vissink A. Links between periodontal disease and general health. 1. Pneumonia and cardiovascular disease. Ned TijdschrTandheelkd. 2006;113(5):186-90. https://www.ncbi.nlm. nih.gov/pubmed/16729563.

6. Inomata M., Ishihara Y., Matsuyama T. et al. Degradation of vascular endothelial thrombomodulin by arginine- and lysine-specific cysteine proteases from Porphyromonas gingivalis. Periodontol. 2009;80(9):1511-1517. doi: 10.1902/jop.2009.090114.

7. Deo V., Bhongade M.L. Pathogenesis of periodontitis: role of cytokines in host response. Dent. Today. 2010;9(29):60-69. https://www.ncbi. nlm.nih.gov/pubmed/20973418.

8. Pupin T.I., Nemesh 0.M., Honta Z.M. et al. Suchasni aspekty likuvannia heneralizovanoho parodontytu v osib z somatychnoiu patolohieiu. Zaporizkyi medychnyi zhurnal. 2020;1:222-226. doi: 10.14739/23101210.2020.1.194649. (in Ukrainian). 
9. Shyrikhanova I.Yu., Honta Z.M., Nemesh O.M. Modeli likuvannia ta alternatyvni skhemy vedennia parodontolohichnykh khvorykh. Novyny stomatolohii. 2019;3:12-16. (in Ukrainian).

10. Bragin A.V. Individual'no-tipologicheskiye osobennosti sistemnogo krovoobrashcheniya, fizicheskoy rabotosposobnosti i regulyatsii serdechnoy deyatel'nosti u lits s razlichnoy ustoychivost'yu k zabolevaniyam parodonta. Stomatologiya. 2008:3:28-31. (in Russian).

11. Zabolotnyi T.D., Skalat A.P. Funktsionalni metody diahnostyky pochatkovykh stupeniv heneralizovanoho parodontytu u khvorykh iz vpershe diahnostovanym tuberkulozom lehen. Halytskyi likarskyi visnyk. 2013;1:23-26. (in Ukrainian).

12. Dzgoyeva M.G. Sostoyaniye pul'sovogo krovenapolneniya tkaney parodonta patsiyentov pri fonovoy patologii sistemnoy gemodinamiki. Stomatologiya; 2008; 3: 32-35. (in Russian).

13. Zabolotnyi T.D., Borysenko A.V., Markov A.V., Shylivskyi I.V. Heneralizovanyi parodontyt. Lviv: HalDent, 2011:240 p. (in Ukrainian).

14. Wang Q., Zhou X., Huang D. Role for Porphyromonas gingivalis in the progression of atherosclerosis. Med Hypotheses. 2009;72(1):71. doi: 10.1016/j.mehy.2008.04.030.

15. Saygun I., Nizam N., Keskiner I. et. al. Salivary infectious agents and periodontal disease status. J. Periodontal. Res. 2011;46(2):235-239. doi: 10.1111/j.1600-0765.2010.01335.x.

16. Catapano A.L., Reiner Z., De Backer G. et al. ESC/EAS Guidelines for the management of dyslipidaemias: the Task Force for the management of dyslipidaemias of the European Society of Cardiology (ESC) and the European Atherosclerosis Society (EAS). Atherosclerosis. 2011;217(1):144. doi: 10.1016/j.atherosclerosis.2011.06.012.

17. Friedewald V.E., Kornman K.S., Beck J.D. et al. The American Journal of Cardiology and Journal of Periodontology editors' consensus: periodontitis and atherosclerotic cardiovascular disease. J Periodontol. 2009;80(7):1021-1032. doi: 10.1902/jop.2009.097001.

18. Serra e Silva Filho W., Casarin R.C., Nicolela E.L. et al. Microbial diversity similarities in periodontal pockets and atheromatous plaques of cardiovascular disease patients. PLoS One. 2014;9(10): 109. doi: 10.1371/journal.pone.0109761.

19. KozarovE. Bacterial invasion of vascular cell types: vascular infectology and atherogenesis. Future Cardiol. 2012;8(1):123-138. doi: 10.2217/fca.11.75.

20. Oliveira F.J., Vieira R.W., Coelho O.R. et al. Systemic inflammation caused by chronic periodontite in patients victims of acute ischemic heart attack. Rev Bras Cir Cardiovasc. 2010;25(1):51-58. doi: 10.1590/ s0102-76382010000100013.

21. Lee H.R., Jun H.K., Kim H.D. et. al. Fusobacterium nucleatum GroEL induces risk factors of atherosclerosis in human microvascular endothelial cells and ApoE(-/-) mice. Mol. Oral Microbiol. 2012;27(2):109-123. doi: 10.1111/j.2041-1014.2011.00636.x.

22. Bartova J., Sommerova P., Lyuya-Mi Y. et al. Periodontitis as a risk factor of atherosclerosis. J Immunol Res. 2014;1:636-893. doi: $10.1155 / 2014 / 636893$.

23. Yucel-Lindberg T., BâgeT. Inflammatory mediators in the pathogenesis of periodontitis. Expert Rev Mol Med. 2013;15:7. doi: 10.1017/erm.2013.8.

24. Hasturk H., Kantarci A., Van Dyke T.E. Oral inflammatory diseases and systemic inflammation: role of the macrophage. Front Immunol. 2012;3:118. doi: 10.3389/fimmu.2012.00118.

25. Taleb S. Inflammation in atherosclerosis. Arch Cardiovasc Dis. 2016;109(12):708-715. doi: 10.1016/j.acvd.2016.04.002.

26. Beloklitskay. G.F.. Kopcha. 0.V. Novyye mekhanizmy patogeneza generalizovannogo parodontita pri kardiovaskulyarnoy patologii. Stomatologiya. Estetika. Innovatsii. 2017;1(1):22-31. (in Russian).
27. Kopchak 0.V. Patohenetychne obgruntuvannia novykh pidkhodiv do likuvannia heneralizovanykh zakhvoryuvan parodonta u patsientiv z endotelialnoyu dysfunktsieyu pry kardiovaskulyarniiy patolohii (Avtoref. dys... doktora med. nauk: 14.01.22 Stomatolohiia). Kyiv, 2018:43p. (in Ukrainian).

28. Saveleva N.N., Sokolova I.I., German S.I., Tomilina T.V. Some aspects of the eatiology of parodontus diseases. (Literature review). Ukrainian Dental Almanac. 2018;2:54-59. (in Ukrainian).

29. Yarova S.P., Alekseyeva V.S. Osobennosti rasprostraneniya i techeniya vospalitel'no-distroficheskikh protsessov v parodonte na fone zabolevaniy zheludochno-kishechnogo trakta. Ukraínskii stomatologíchnii almanakh. 2014;2:105-107. (in Russian).

30. Chornii N.V. Rozpovsiudzhenist ta osoblyvosti klinichnykh proiaviv zakhvoriuvan tkanyn parodonta u khvorykh na khronichnyi pankreatyt. Bukovynskyi medychnyi visnyk. 2014;2(18):116-119. (in Ukrainian).

31. Manashchuk N.V. Rozpovsiudzhenist ta klinichnyi perebih zakhvoriuvan parodonta na tli khronichnykh kolitiv. Visnyk problem biolohii i medytsyny. 2014;2(1):239-241. (in Ukrainian).

32. Neyzberg D.M.,StyufI.YU. Rol'ektopicheskikh ochagov Helicobacter pylori pri khronicheskom generalizovannom parodontite. Parodontologiya. 2011;2(59):9-13. (in Russian).

33. Sokolova I.I., Ryabokon' Ye.N., Oleynichuk V.V. Vidovoy sostav anaerobnoy mikroflory parodontal'nykh karmanov u bol'nykh generalizovannymi formami parodontita na fone patologii organov zheludochno-kishechnogo trakta. Eksperimentalna í klíníchna meditsina. 2013;4(57):46-48. (in Russian).

34. Ryabokon'Ye.N., Sokolova I.I., Oleynichuk V.V. Patomorfologicheskiye izmeneniya v epitelii parodontal'nykh karmanov u bol'nykh generalizovannym parodontitom, sochetannym syazvennoy bolezn'yu. Vísnik problem bíologíi í meditsini. 2013;4:342-346. (in Russian).

35. YesayanZ.V. Klinicheskaya kharakteristika sostoyaniya tkaney parodonta u bol'nykh s khronicheskim nespetsificheskim yazvennym kolitom. Ukraínskii stomatologíchni almanakh. 2012;1:32-35. (in Russian).

36. Kashivska R.S. Stan tkanyn parodonta u khvorykh na heneralizovanyi parodontyt pryzakhvoriuvanniakh hepatobiliarnoisystemy ta obhruntuvannia medykamentoznoi korektsii vyiavlenykh porushen (Dys. ... kand. med. nauk: 14.01.22 Stomatolohia). Ivano- Frankivsk, 2016:204p. (in Ukrainian).

37. Sichkoriz Kh.A., Minko L.Yu. Zminy fizyko-khimichnykh vlastyvostei rotovoi ridyny u khvorykh iz zakhvoriuvanniamy parodonta na foni khronichnoho hepatytu ( pid chas protyvirusnoi terapii. Ukrainskyi stomatolohichnyi almanakh. 2016;3:13-17. (in Ukrainian).

38. Fesenko V.I., Shvets S.V. Kliniko-imunolohichnyi status khvorykh na heneralizovanyi parodontyt na tli virusnoho hepatytu B. Ukrayinskyi stomatolohichnyi almnakh. 2016;4: 8-31. (in Ukrainian).

39. Humeniuk M. I., Mazur I.P., Ihnatieva V.I. et al. Osoblyvosti klinichnykh proiaviv patolohichnykh protsesiv parodonta u khvorykh na khronichne obstruktyvne zakhvoriuvannia lehen. Ukraynskyy pul'monolohycheskyy zhurnal. 2011;1:40-44. (in Ukrainian).

40. Kharchenko-Sevriukova H.S. Kliniko-imunolohichni osoblyvosti perebihu heneralizovanoho parodontytu u khvorykh na khronichne obstruktyvne zakhvoriuvannia leheniv. Astma ta alerhiia. 2015;1:45-50. (in Ukrainian).

41. Linden G.J., Lyons A., Scannapieco F. A Periodontal systemic associations: review of the evidence. J. Clin. Periodontol. 2013;40(14):819. doi: 10.1111/jcpe.12064.

42. Slobodian V.V., Oliinyk 0.V. Vplyv endotoksykozu na proiavy hipoksii pry likuvanni khvorykh khirurhichnoho profiliu na suputni khronichni obstruktyvni zakhvoriuvannia lehen. Visnyk naukovykh doslidzhen. 2016;2:54-56. (in Ukrainian). 
ORCID and contributionsyip:

Oksana M. Nemesh: 0000-0002-1768-8281 $1^{A, D}$

Zoriana M. Honta: 0000-0001-9180-823X ${ }^{B, F}$

Oksana M. Slaba: 0000-0003-4566-7178 $8^{A, E}$

Ihor V. Shylivskyi: 0000-0001-8544-1398

\section{Conflict of interest:}

The Authors declare no conflict of interest.

\section{CORRESPONDING AUTHOR}

Zoriana M. Honta

Danylo Halytsky Lviv National Medical University,

69 Pekarska st., 79010 Lviv, Ukraine

tel: +380505905747

e-mail: zoryanagonta@gmail.com

Received: 23.11 .2020

Accepted: 29.03.2021

A - Work concept and design, B - Data collection and analysis, C - Responsibility for statistical analysis,

D-Writing the article, $\mathbf{E}$-Critical review, $\mathbf{F}$ - Final approval of the article 